GRADIATION\&APPLICATIONS

ISSN 2466-4294 (online) | rad-journal.org

Vol. 2 | Issue 2 | pp. 139-141, 2017

doi: 10.21175/RadJ.2017.02.029

Short note

\title{
RADIOMODIFICATION OF CELL CULTURES OF LINE HELA BY CERIUM OXIDE NANOPARTICLES TO X-RAY IRRADIATION ${ }^{*}$
}

\author{
Ruslan Vazirovi $^{* *}$, Sergei Sokovnin ${ }^{1,2}$, Maria Ulitko',3 \\ ${ }^{1}$ Ural Federal University, Yekaterinburg, Russia \\ ${ }^{2}$ Institute of Electrophysics UB RAS, Yekaterinburg, Russia \\ 3Institute of Medical Cell Technologies, Yekaterinburg, Russia
}

\begin{abstract}
Postradiation complications that appeared after radiotherapy are considered the most serious problem in the treatment of various types of cancer diseases. Therefore, the research of radiomodification properties of nanoparticles is highly relevant. The aim was to study the biological activity of cerium oxide nanoparticles (CONP). CONPs were obtained by pulsed electron beam evaporation in the low gas pressure on installation NANOBIM-2. A feature of this method is the preparation of nanoparticles with a large number of structural defects of various kinds, which gives them unique physical properties, and allows expecting a high biological activity. A solution of CONPs was introduced into a normal breeding medium of the cell cultures in Petri dish to a concentration of $50-500 \mathrm{mcg} / \mathrm{ml}$. To stabilize the CONPs, we used sodium citrate. Samples were irradiated on arrangement of Xstrahl 300 with $200 \mathrm{keV}$ energy of $X$-ray and, after three days, CONPs have been added. The samples were irradiated to the absorbed doses of 5, 7.5, 10 Gy. To control the absorbed doses, we used the DTG - 4 thermo luminescent dosimeters (LiF). The analysis of biological response was performed using the Goryaeva chamber and the MTT test. The results allow us to make preliminary conclusions that the early addition of low concentrations (up to $50 \mathrm{mcg} / \mathrm{ml}$ ) of CONPs will increase the sensitivity of cancer cells line Hela to radiation. Thus, the CONPs could be universal radiomodifiers to radiotherapy and their properties require subsequent studies.
\end{abstract}

Key words: Radiation, radiomodification, sensitivity, cancer, nanoparticles, cerium, oxide cerium, CONP, Hela

\section{INTRODUCTION}

An important and promising property of nanoparticles (NP) for applications is radiomodification of biological objects exposed to ionizing radiation.

In [1], an increased radiosensitivity of colorectal in vitro and in vivo cancer was observed when gold NP with the concentration of $250 \mathrm{mcg} / \mathrm{mL}$ was administered. A dose reduction factor (DRF) for the cell culture was 1.69, and the tumor growth in laboratory animals after combined exposure to NPs and ionizing radiation increased almost twice. These results demonstrate a substantial change in radioresistivity of tissue with the addition of the NPbased radiomodifier in low concentrations.

In [2] and [3], the antioxidant properties of CONPs are described, binding the ability of cerium to be in two valence states $-3+$ and $4+$. Cerium oxide is actively involved in redox reactions, increasing or decreasing reactive oxygen species (ROS) in cells and extracellular environment. In an alkaline medium, trivalent cerium is easily oxidized to the tetravalent while interacting with the ROS and reducing their quantity and, in the acidic environment, the tetravalent cerium is unstable. It acts as a strong oxidizing agent. It should be noted that the pathological cancer tissue lives in an acid environment with $\mathrm{pH}<7$, so that the CONPs should be toxic to tumor cells.

The concentration of $\mathrm{Ce}_{3}+$ oxide in a crystal structure of NP depends on several parameters: first, on the size of NP - the smaller the diameter of the cerium dioxide nanocrystals is, the more cerium atoms with a valence of $3^{+}$they contain; second parameter influencing the valence of cerium is the $\mathrm{pH}$ of the medium - if the $\mathrm{pH}<7, \mathrm{Ce} 4+$ will go into $\mathrm{Ce}_{3}+$.

The unique chemical and physical properties of cerium nanoparticles [4] allow them to be used for radioprotection of human healthy tissue during radiation therapy and nuclear medicine [5] and, at the same time, to increase the radiosensitivity of pathological tissues. Research [6] showed that the preliminary introduction of CONPs into the cells of pancreatitis increases the sensitivity to ionizing radiation $-\mathrm{DRF} \approx 1.7$, and, conversely, for the cells of the pancreas radioresistivity increases, with DRF of around 0.93. Such a selective influence of CONPs is

\footnotetext{
* The paper was presented at the Fifth International Conference on Radiation and Applications in Various Fields of Research (RAD 2017), Budva, Montenegro, 2017.

vazirov23@gmail.com
} 
R. Vazirov et al., Radiomodification of cell cultures of line Hela..., Rad. Applic., 2017, 2, 2, 139-141

due to the different $\mathrm{pH}$ of the medium in healthy and pathological tissues [6]. Cerium in an alkaline medium tends to $4+$ valence, at the same time it actively fights against the ROS, formed by ionizing radiation. In an acidic medium, the structure of CONPs lattice changes due to the increase in atoms with $3+$ valence which is toxic and generates ROS. Radiomodification of CONPS pathological tissue increases the efficiency of exposure to ionizing radiation. Moreover, if we consider the ability of CONPs to inhibit cancer metastasis, cerium becomes a potentially highly effective cure for malignant tumors.

Thus, the use of NPs in radiation therapy as radiomodifiers is a highly discussed area of research.

The purpose of this research was to study the biological activity of CONPs. CONPs concentrations of up to $500 \mathrm{mcg} / \mathrm{mL}$ [7] obtained by a pulsed electron beam evaporation in the low pressure gas on installation NANOBIM-2 [8] were introduced into the culture medium of samples of cell cultures in Petri dishes. A feature of this method is the preparation of nanoparticles with many structural defects of various kinds, which gives them unique physical properties, and allows one to expect a high biological activity. The determining factor increasing the biological activity of NPs is the crystal lattice defectiveness. Large number of defects in the crystal lattice of CONPs lead to formation of oxygen vacancies and presence different ions in the crystal lattice, as a result CONPs actively enter into redox reactions.

\section{MATERIALS AND METHODS}

To study the biological activity of nanoparticles of cerium dioxide (CONPs) in combination with the ionizing radiation on cancer cells, transplantable lines of human cervical carcinoma Hela, obtained from the Russian Collection of Cell Cultures, Institute of Cytology RAS, St. Petersburg, Russia, were used.

CONPs were produced by pulsed electron beam evaporation in the low gas pressure on installation NANOBIM-2. The CONPs powders have a fractal structure and consist of agglomerates of sizes from dozens to hundreds of nanometers formed by crystalline nanoparticles $3-5 \mathrm{~nm}$ in size with a very narrow particle size distribution [4].

Cells were seeded in 96-well plates in the inoculum dose of $2 \times 10^{5}$ cells / $\mathrm{mL}$ and cultured for 24 hours in "Igla", Dulbecco's Modified Eagle Medium(DMEM), with $1 \%$ glutamine in the presence of $10 \%$ fetal calf serum and gentamicin (50 $\mathrm{mg} / \mathrm{L})$ at $37^{\circ} \mathrm{C}$, with humidified atmosphere of $5 \% \mathrm{CO}_{2}$, after which the nanoparticles of various concentrations were added to the wells. Cells were incubated with CONPs for 72 hours and then were irradiated with X-rays at 200 keVat Xstrahl 300 installation. Samples were irradiated with an absorbed dose of 5, 7.5, $10 \mathrm{~Gy}$.

The control of the absorbed dose was carried out by means of thermo-luminescent dosimeters DTG-4 (LiF).

The evaluation of the cell viability was conducted by means of a standard MTT test in 72 hours after irradiation, by comparing the optical density of the formazan solution, measured by a flatbed scanner at a wavelength of $490 \mathrm{~nm}$ in the experimental and control wells (culture medium). Experiments were performed in 4 replicates with a negative (culture medium) and positive (1 mM hydrogen peroxide solution in PBS) controls.

\section{RESULTS}

The data obtained after processing the results of MTT test are shown in Figure 1. The results confirm the increase of radiation sensitivity of cancer cells of the Hela line with the addition of CONPs. The concentration level of $50 \mathrm{mcg} / \mathrm{mL}$ (0.95 confidence interval) leads to the increased inactivation of tumor cells - the subsequent increase of concentration is not effective for the radiomodification increase.

This is due to the transition of cerium into the $3^{+}$ oxidation state, associated with size of NPs and a more acidic $\mathrm{pH}$ of cancer cells. Under these conditions, many oxygen vacancies are observed in the crystal lattice structure. However, results at 10 Gy irradiation with adding different concentrations of CONPs are dissonant - lower concentrations of CONPs reduce survival of Hela cells.

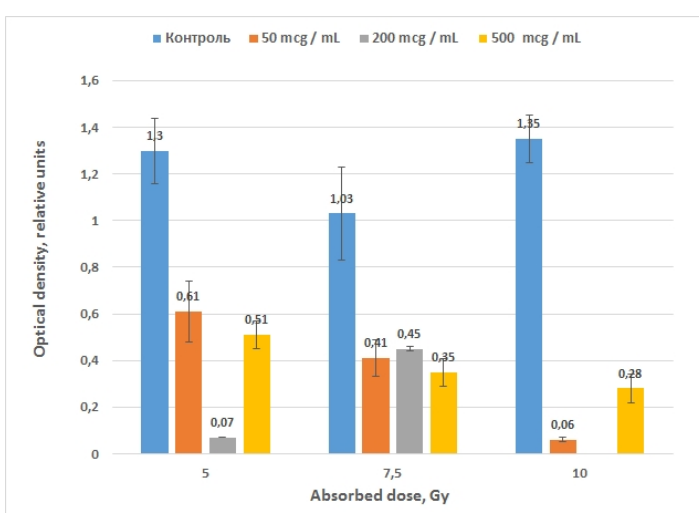

Figure 1. The viability of cell cultures samples irradiated with 5, 7.5 and 10 Gy. 1) Control Group o $\mathrm{mcg} / \mathrm{mL} 2$ ) Adding CONPs $50 \mathrm{mcg} / \mathrm{mL}$ 3) Adding CONPs $200 \mathrm{mcg} / \mathrm{mL} 4$ ) Adding CONPs $500 \mathrm{mcg} / \mathrm{mL}$

One of the indicators used to increase the effect of radiation on biological objects is the performance index of the effect, defined as the ratio of the biological radiomodification response to the control sample without it with the same absorbed dose of the samples. Table 1 shows some performance indexes of the effect for different absorbed doses and concentrations in relation to CONPs samples without adding CONPs.

Table 1. Performance Index of radiomodifier (protection factor)

\begin{tabular}{|c|c|c|c|}
\hline \multirow{2}{*}{ NP concentration, mcg / mL } & \multicolumn{3}{|c|}{ Performance Index } \\
\cline { 2 - 4 } & 5 Gy & $7.5 \mathrm{~Gy}$ & $10 \mathrm{~Gy}$ \\
\hline 50 & 0.47 & 0.40 & 0.04 \\
\hline 200 & 0.05 & 0.44 & 0.52 \\
\hline 500 & 0.39 & 0.34 & 0.21 \\
\hline
\end{tabular}


The resulting compound is toxic in relation to the environment and contributes to the generation of reactive oxygen species, which probably resulted in the inactivate cell increase. Figure 2 shows the doseresponse curves.

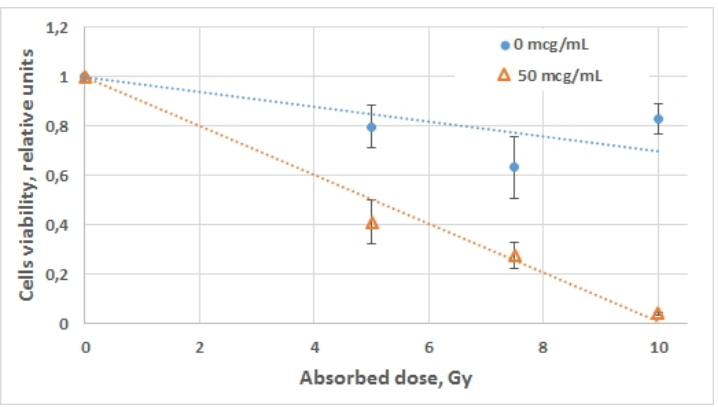

Figure 2. Survival curve of Hela cells treated with $(\bullet)$ radiation alone, $(\Delta)$ CONPs $50 \mathrm{mcg} / \mathrm{mL}+$ radiation

\section{Discussion}

Presently, chemically produced nanoparticles are used in research. This method of production is characterized as "bottom-up" transition. However, it is not universal - the production of NPs by "top-down" transition, i.e. by the physical methods, has its own advantages. Physical methods of NP production allow one to get the nonequilibrium NPs of metal oxides, which have unique physical, chemical, structural and thermal properties [9].

The advantages of the chemical method remain in a relative ease of production and in its high performance. However, medicine does not require big NPs and physical and chemical properties are of high importance. Numerous studies of the combined effect of NPs and ionizing radiation support the use of NP as radiomodifiers.

\section{CONCLUSIONS}

The obtained dose-response curves clearly show the presence of CONPs radiosensibilitizing effect on cancer cells. DRF for a CONPs concentration of $50^{\circ} \mathrm{mcg}^{\circ} /{ }^{\circ} \mathrm{mL}$ was 3.27 .

The results are preliminary and require further investigation. However, they characterize CONPs as potential radiomodifiers for cancer treatment.

Acknowledgement: We express our gratitude to Dr. V.G. Il'ves, Institute of Electrophysics UB RAS provided NCHDS and Dr. L.N. Izyurov, Sverdlovsk Regional Oncology Center for help with the work at the facility Xstrahl 30o. This work was supported by the Russian Science Foundation, project No 16-1604038 .

\section{REFERENCES}

1. M. Shi, B. Paquette, T. Thippayamontri, L. Gendron, B. Guerin, L. Sanche, "Increased radiosensitivity of colorectal tumors with intra-tumoral injection of low dose of gold nanoparticales," International Journal of Nanomedicine, vol. 11, pp. 5323-5331, Oct. 2016.

DOI: 10.2147/IJN.S97541

PMid: 27789945

PMCid: PMC5068480

2. А. Б. Щербаков, Н. М. Жолобак, В. К. Иванов, Ю. Д. Третьяков, Н. Я. Спивак, “Наноматериалы на основе диоксида церия: свойства и перспективы использования в биологии и медицине," Biotechnologia Acta, т. 4, № 1, стр. 9-28, 2011. (A. B. Shcherbakov, N. M. Zholobak, V. K. Ivanov, Yu. D. Tretyakov, N. Ya. Spivak, "Nanomaterials based on the nanocrystalline Ceric Dioxide: Properties and the use perspectives in Biology and Medicine," Biotechnologia Acta, vol. 4, no. 1, pp. 9-28, 2011.)

Retrieved from:

http://biotechnology.kiev.ua/storage/2011/\%231 2011/S herbakovNo\%201.pdf

Retrieved on: Jan. 17, 2017

3. Y. Xue, Q. Luan, D. Yang, X. Yao, K. Zhou, "Direct evidence for hydroxyl radical scavenging activity of cerium oxide nanoparticles," The Journal of Physical Chemistry C, vol. 115, no. 11, pp. 4433-4438, Mar. 2011. DOI: $10.1021 /$ jp109819u

4. V. Il'ves, S. Yu. Sokovnin, "Production and studies of properties of nanopowders on the basis of $\mathrm{CeO} 2$," Nanotechnologies in Russia, vol. 7, no. 5, pp. 213-226, May 2012. DOI:10.1134/S1995078012030068

5. M. K. Bakht, V. Hosseini, H. Honarpisheh, "Radiolabeled nanoceria probes may reduce oxidative damages and risk of cancer: A hypothesis for radioisotope-based imaging procedures," Medical Hypotheses, vol. 81, no. 6, pp. 11641168, Dec. 2013.

DOI: 10.1016/j.mehy.2013.10.008

PMid: 24210631

6. M.S. Wason, J. Colon, S. Das, S. Seal, J. Turkson, J. Zhao, C. H. Baker, "Sensitization of pancreatic cancer cells to radiation by cerium oxide nanoparticle-induced ROS producion," Nanomedicine: Nanotechnology, Biology, and Medicine, vol. 9, no. 4, pp. 558-569, May 2012.

DOI: $10.1016 /$ j.nano.2012.10.010

PMid: 23178284

PMCid: PMC3606274

7. V. G. Il'ves, S. Yu. Sokovnin "Production and studies of properties of nanopowders on the basis of $\mathrm{CeO} 2$," Nanotechnologies in Russia, vol. 7, no. 5, pp. 213-226, May 2012.

DOI: $10.1134 / \mathrm{S} 1995078012030068$

8. S. Yu. Sokovnin, V. Il'ves "Production of nanopowders using pulsed electron beam," Ferroelectrics, vol. 436, no. 1, pp. 101-107, 2012. DOI: $10.1080 / 10584587.2012 .730951$

9. S. Yu. Sokovnin, V. G. Il'ves, M. G. Zuev, "Production of complex metal oxide nanopowders using pulsed electron beam in low pressure gas for BioMaterials application." in Engineering of Nanobiomaterials: Applications of Nanobiomaterials, vol. 2, A. M. Grumezescu, Ed., USA: Elsevier Inc., 2016, ch. 2., pp. 29-75.

DOI: 10.1016/B978-0-323-41532-3.00002-6 